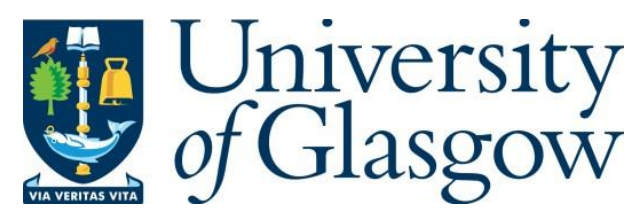

Arshed, N., Mason, C. and Carter, S. (2016) Exploring the disconnect in policy implementation: A case of enterprise policy in England. Environment and Planning C: Government and Policy, 34(8), pp. 1582-1611.

There may be differences between this version and the published version. You are advised to consult the publisher's version if you wish to cite from it.

http://eprints.gla.ac.uk/118278/

Deposited on: 16 March 2020

Enlighten - Research publications by members of the University of Glasgow http://eprints.gla.ac.uk 


\title{
EXPLORING THE DISCONNECT IN POLICY IMPLEMENTATION: A CASE OF ENTERPRISE POLICY IN ENGLAND
}

\begin{abstract}
Previous studies have acknowledged the ineffectiveness of enterprise policy. However, the reasons for its ineffectiveness remain a matter for debate. This study examines the extent to which the ineffectiveness of enterprise policy can be attributed to the way it has been implemented. Interviews with central government policy-makers, Regional Development Agency staff and business development managers in local enterprise agencies during the Labour administration (2007-2010) revealed that the implementation process of enterprise policy initiatives is complex and confusing, with fragmented relationships between the actors involved. The abundance of enterprise policy initiatives being delivered at the time, the absence of clearly defined objectives, the limited emphasis on the delivery of business support and the lack of measurement and evaluation combined to create an unnecessarily complicated process of enterprise policy implementation which, in turn, reduced its effectiveness.
\end{abstract}

Keywords: enterprise policy, entrepreneurship, implementation, policy process, England 


\section{Introduction}

Entrepreneurship is one of the key drivers of economic and social development (Audretsch and Beckmann, 2007; Doh and Kim, 2014). In the UK, various forms of enterprise policies have been in place since the 1970s, following the publication of the Bolton Report (1971). The 1970s represented an emergent phase which saw the introduction of enterprise policy addressing market failures in advice and support provision for entrepreneurs and SMEs (Bennett, 2008; Blackburn and Schaper, 2012). The early 1980s saw initiatives ${ }^{1}$ designed to encourage start-ups with financial incentives, such as the Enterprise Allowance Scheme and the Loan Guarantee Scheme, to promote economic growth and create employment (Greene, 2002; Hart, 2003). In the 1990s emphasis shifted towards a 'softer' method of support in the form of advice, consultancy, information and training offered through Business Link to SMEs which showed potential for growth (Greene et al, 2004; Greene and Patel, 2013). Since the late 1990s the UK has taken a more balanced approach: improving productivity and while at the same time prioritising social inclusion (Greene and Patel, 2013). However, 'despite three generations of enterprise policies there remains identifiable and stubborn failings in the attempts to create sustainable small business economies throughout the United Kingdom' (Beresford, 2015, 2).

There is little tangible evidence over a ten-year period (1999-2009) that enterprise policies resulted in increased business start-up rates or improved the contribution of growing firms to employment and economic growth ${ }^{2}$ (Bannock, 2005; Bennett 2006; National Audit Office, 2006; Greene et al, 2008; Huggins and Williams, 2009; Bridge, 2010; Brown and Mason, 2012; Williams, 2013). The effectiveness of 'government intervention is therefore increasingly open to debate' (Pickernell et al, 2015, 5). One emerging perspective has attributed the ineffectiveness of enterprise policy to the way in which it is formulated (Arshed 
and Carter, 2012; Arshed et al, 2014). An alternative view contends that the principal source of its ineffectiveness lies at the implementation stage on account of the complexity of such policies to administer (Bennett, 2008; Niska and Vesala, 2013). Although the policy studies literature identifies 'implementation failure' as a factor in the ineffectiveness of policy (Barrett, 2004), this perspective has only recently been acknowledged in the enterprise policy literature as a potential source of ineffectiveness. Those entrepreneurship studies that have focused on the implementation of enterprise policy (Mole, 2002; Xheneti and Kitching, 2011; Niska and Vesala, 2013; Vega et al, 2013) have fallen short of unlocking the 'black box' which harbours the intricacies of how policy is delivered and who is involved at the implementation stage of the policy process.

The importance of effective implementation and delivery ${ }^{3}$ of policy has been at the forefront of UK policy-making since the General Election of 2001 when the 'reform and delivery of public services became the defining theme of the second Blair administration' (Lee 2004, 12). A review of the evidence on effective implementation has been described as 'imperfect' (Grimshaw et al, 2003), with critics arguing that the quality of policy implementation correlates with its effectiveness (Bozeman, 2013). In a recent government report by the Cabinet Office (2015) titled Implementation profession: tools for implementing policy several reasons are given as to why implementation fails. These include, inter alia, policy being formed without consideration of implementation; little consultation with external stakeholders; insufficiently clear goals and outcomes; lack of skills in the implementation process; and a lack of incentives to deliver policies and little accountability for implementation (Cabinet Office, 2015).

In light of the continuing prevalence of policy failures (Barrett, 2004; O’Toole, 2004; Theodoulou and Kofinis, 2004) there have been increasing calls for rigorous studies that can identify the particular conditions under which successful enterprise implementation and 
delivery takes place (Storey, 2002; Davies, 2004). Many government evaluations only consider short-term effects because the indicators being measured have yet to emerge or have any impact on those exploiting the policy initiative (Gibb, 1993; Curran and Storey, 2002; Cowie, 2012; Jones et al, 2013). This, in turn, suggests that the prospect of learning from previous policy measures is virtually non-existent (Rush et al, 2004) because if robust evaluation existed, the process establishes the impact of enterprise policies and programmes from several perspectives: ex-ante (focussing on the likely impact), implementation and expost (Lenihan, 2011). The evaluation of enterprise policy will naturally indicate whether the activities and initiatives implemented have achieved the specified objectives (Theodoulou and Kofinis, 2004). Evaluation is therefore the key to good policy implementation (DeLeon and DeLeon, 2002).

This paper addresses two main research questions. First, how have enterprise policy initiatives been implemented in the UK? This is accomplished by an exploration of the process and the actors involved. Second, to what extent does the implementation of enterprise policy explain its ineffectiveness? These questions are addressed by means of an examination of the way in which the Labour Government's enterprise policy initiatives were implemented during their final year in office (2009-10). This paper can be seen as an initial response to the call to 'place more emphasis upon the process by which policy is developed and implemented rather than focussing entirely upon outcomes' (Patton et al, 2003, 823). The study focuses solely on England as in Scotland, Wales and Northern Ireland, the devolved administrations have different institutional arrangements and there is less 'evidence of a fragmentation of service delivery organisations or the same unintended consequences associated with the pursuit of a top-down policy style' (Cairney, 2009, 356).

Drawing on individual in-depth, semi-structured interviews with policy-makers (i.e. civil servants), Regional Development Agency (RDA) ${ }^{4}$ staff and local enterprise agencies, 
this paper explores the policy implementation process to provide a unique insight into how enterprise policy was delivered in this time-period. It is important to emphasise at the outset that the paper does not aim to measure the effectiveness of enterprise policy. Rather, by exploring the involvement of multiple actors across various levels, the paper makes two contributions to the enterprise policy debate. First, it examines how enterprise policy was implemented, a stage of the policy process that has previously been unexplored as a potential underlying source of its ineffectiveness. Valuable insights emerge by shifting the focus of analysis away from institutions and their goals to concentrate on the incentives, beliefs and abilities of those individuals involved to understand the process of delivery itself. Second, it explores the relationships between the key actors (policy-makers, RDA staff and business development staff in local enterprise agencies) involved in the policy process. This is also significant since the delivery of policy initiatives depend implicitly on the individual(s) who is known as the 'street level bureaucrat' (Weatherley and Lipsky, 1977; Lipsky, 1980; McLaughlin, 1987). Although, the street level bureaucrat is important, many policy initiatives involve more than one individual or organisation because of the inter-dependent networks involved in the complex process of implementation (Fudge and Barrett, 1981; Dorey 2005; Cairney, 2009).

The paper is structured as follows. Section 2 provides a comprehensive review of the key literature relating to the implementation of enterprise policy in the UK. Section 3 presents the methodological approach taken. Section 4 covers the key findings. Section 5 reflects on these findings, in particular, how enterprise policy is implemented and who is involved. The final section also offers some concluding remarks and reflections for the future of enterprise policy implementation. 


\section{Implementation of enterprise policy}

Easton $(1957,384)$ defines policy as an 'authoritative allocation of values for the whole society.' Building on this, policy is often seen as a statement by government of what it intends to do whether it be through law, regulation, ruling, decision, order or a combination of these (Birkland, 2014). Kingdon (1984: 3) defines public policy-making as constituting a 'set of processes, including at least (1) the setting of an agenda, (2) the specification of alternatives from which a choice is to be made, (3) an authoritative choice among those specified alternatives... and (4) the implementation of a decision.' This description merges the politics, the policies, and the problem streams (Weible et al, 2012). The scope of this study is restricted to the implementation stage of enterprise policy which involves the "process of interaction between the setting of goals and action geared to achieving them' (Pressman and Wildavsky, 1977, XV), it is seen as subsequent to agenda setting and policy formulation (Hupe and Hill, 2015).

Enterprise policy has emerged as one of the key 'policies of choice' for governments around the world for tackling social and economic challenges (Wright et al, 2015; O'Connor, 2015). Various enterprise policy studies have been undertaken in different contexts (Gibb and Haas, 1996; Lundstrom and Stevenson, 2005; North and Smallbone, 2006; Hülsbeck and Lehmann, 2007; Smallbone and Welter, 2010; Van Cauwenberge et al, 2013; Arshed et al, 2014). However, closer scrutiny of the policy process and the participating actors involved is warranted. A basic dilemma for governments is whether to concentrate on entrepreneurship policy - encouraging the creation of new enterprises (Nolan, 2003), or SME policy supporting existing firms (Audretsch, 2004). Entrepreneurship policies make greater use of 'soft' policy measures such as mentoring, advisory services and entrepreneurship promotion to encourage the creation of new enterprises (Wren and Storey, 2002; Lundstrom et al, 2005). 
SME policies make use of 'hard' policy instruments which include a range of financial measures such as direct grants, subsidised loans, loan guarantees, enhancing technology and access to technology, and increasing initiatives to make venture capital more readily available (Wren and Storey, 2002; Lambrecht and Pirnay, 2005).

There is, nevertheless, considerable overlap in their shared goal of encouraging and pursuing economic prosperity (Department for Business Enterprise and Regulatory Reform, 2008; Lenihan, 2011). 'Both seek to improve the performance of economic actors (entrepreneurship policy is focused on the key actors in the business, the entrepreneurs, while SME policy seeks to increase the competitiveness of the firm) and both seek to increase the number of economic actors (entrepreneurship hoping to increase the level of supply of entrepreneurs, while SME policy hopes to increase the number of competitive firms)' (Rigby and Ramlogan, 2013, 4). This is in accordance with UK norm (Lenihan, 2011; Arshed et al, 2014) where 'traditionally, enterprise policy has centred on business start-ups and support for small-business growth' (Huggins and Williams, 2009, 21) to improve individual and societal economic development (Blackburn and Ram, 2006. Enterprise policy is defined here as including both entrepreneurship policy and SME policy.

A typology of different approaches to enterprise policy adopted by various governments (Table 1) demonstrates the considerable diversity of policies available (Stevenson and Lundstrom, 2007). The UK takes a holistic approach to enterprise policy which is inclusive of SME policy and entrepreneurship policy. This holistic approach involves reducing barriers to entry and exit, improving access to start-up resources (financing, information and assistance) and addressing the start-up needs of target groups such as the disabled, women, ethnic minorities and the young, and also promotes an entrepreneurial culture, attempting to embed these values within the educational system (Stevenson and Lundstrom, 2007; Verheul et al, 2009; Roper and Hart, 2013). Support for 
firm growth also comes under the holistic approach, whereby support for innovation, organisation development and internationalisation is given to firms typically meeting predefined thresholds of growth (Roper and Hart, 2013).

\section{INSERT TABLE 1 HERE}

Government expenditure in the UK on the range of policy initiatives designed to promote an enterprising society is estimated to have amounted to a total of over $£ 12$ billion between $2003 / 4$ and $2007 / 8$ with $£ 2.4$ billion spent on direct business support schemes in 2003/4 alone (Richard, 2008). This has resulted in over 800 different sources of support for start-ups and SMEs in the UK (Greene and Patel, 2013), a reduction from over 3,000 support schemes since 2003 (Richard, 2008). Enterprise policy initiatives to support entrepreneurs and SMEs have become increasingly complex (Curran and Blackburn, 2000), described as a 'patchwork quilt', 'chaos', 'labyrinth of initiatives' or simply in a 'muddle' (Greene and Patel, 2013). In England support is delivered by both public and private bodies: public bodies include Business Link, RDAs and Local Enterprise Partnerships (LEPs) (Centre for Cities, 2013), while private bodies include banks, accountants or consultants who assist in the delivery of certain funds, such as the GrowthAccelator delivered by Grant Thornton. The array of initiatives means that many actors are involved in the delivery of enterprise policy initiatives.

Various central government departments and agencies are involved in the implementation process (Figure 1). At the time of the study the Department for Business, Innovation and Skills (BIS) was the key player in setting the enterprise agenda. Programmes are executed by ministers at a national level, while at a regional level they fall within the domain of a network of agents (De, 2000). These agents share the responsibility with 
partners (public and private) who, at a local level, become involved in delivering the support to local enterprise agencies and training bodies in the expectation of responding to local needs and simplifying business support (Maville, 2012). Hence, while the government is an enterprise policy-maker, funder and leader, its role does not extend to delivering enterprise policy (Liddle, 2010). The responsibility for enterprise policy and delivery is largely delegated to regional and local government agencies which currently take the form of LEPs (Thompson et al, 2012). Given the complex web of actors and agencies involved, a key question concerns the reality of the process of enterprise policy implementation.

\section{INSERT FIGURE 1 HERE}

The nature of enterprise policy is linked to the mandates of several departments, agencies and non-governmental organisations, covering areas such as trade, foreign relations, immigration and, science and technology. For example, BIS currently works alongside UK Trade \& Investment (UKTI) which provides entrepreneurs and SMEs with various forms of export assistance. The inherent difficulties with the involvement of so many departments in enterprise policy has led governments to increasingly focus their efforts on horizontal policymaking, allowing entrepreneurship to be promoted not only at local levels but also on a national platform (Acs and Szerb, 2007). However, horizontal policy requires the joining of networks and government departments which often leads to difficulties in maintaining relationships due to the complexity and the number of actors involved. Consequently, the process of policy delivery is often difficult and lacks effectiveness (Anechiarico and Jacobs, 1995). Indeed, Storey (2002) argues that in many developed countries, the ability of governments even to specify enterprise policy objectives is difficult and it is common for vague ideas to masquerade as objectives which are ambiguous, confusing and diluted, 
adversely affecting the quality of what is being delivered. So, if enterprise policy has unclear objectives, how is it delivered and what is actually delivered? Furthermore, how are enterprise policy initiatives then evaluated?

The consequence of such equivocal enterprise policy objectives is an 'implementation gap', the difference between what is promised and what is actually delivered (Gilg and Kelly, 1997). Government is aware of the existence of the implementation gap and has acknowledged that policy-makers are required to improve the enterprise policy implementation process (Roper and Hewitt, 2001). Nevertheless, there seems to be little evidence that this 'implementation gap' has been addressed. Rather, there has been a growing proclivity to overlook the gaps in enterprise between what is known and what is understood in the policy process (Gibb, 2000). One reason why this gap has been overlooked relates to the number of actors and departments involved in the process (Richards et al, 1999). Those at the top of the hierarchical ladder tend to concentrate on factors that can be manipulated centrally whereby those at the bottom implement in accordance to their own specific ethos or institutional ideologies, which may, in turn, have particular consequences for how they interpret policy (Dorey, 2005).

There are theories within the policy literature that offer some insights into policy implementation but they provide little understanding why a particular policy could be effective or ineffective (Stoutenborough and Oxley, 2012). As such, there are two main methods of policy implementation which have been developed and are established in policy implementation dialogues: top-down and bottom-up approaches (Figure 1). The top-down approach within policy-making traditionally involves national government policy-makers who formulate the policy, often with little contribution from local or regional actors (Pike et al, 2006). The top-down approach is deeply embedded in the stages model and involves making a clear distinction between policy formulation and implementation (Hill, 2005). It has 
been argued that the UK government has adopted a top-down approach to 'regain control over policy outcomes' (Richards and Smith, 2006, 343). Furthermore, in England enterprise policy is formulated at the 'top' before filtering down to the 'bottom' for delivery (Mole, 2002; Barrett, 2004). Government is assumed to have clear enterprise policy objectives but this is often not the case, especially as the UK has witnessed a development of enterprise policies which have failed to adhere to a clear statement of policy objectives and targets (de Koning and Snijders, 1992; Van Cauwenberge et al, 2013). This is partly due to the response to problems and challenges faced by entrepreneurs and SMEs being largely based on the perceptions of policy-makers regarding what should be in the best interest of the business community rather than involving them in the policy process (Woods and Miles, 2014). Such relationships or the lack of relationships play a critical role in determining not only the impact of the policy but also the effectiveness of it (Friedman, 2003).

Conversely, the bottom-up approach involves the policy implementers, including business advisers, local agencies, and others who implement enterprise policy initiatives and who are in contact with the SME community and entrepreneurs (Urwin and Jordan, 2008). Tummer and Bekkers (2014) argue that those agencies which deliver policy initiatives are on the frontline. The bottom-up approach recognises that goals are ambiguous rather than explicit and may conflict not only with other goals in the same policy area, but also with the norms and motivations of the 'top' level bureaucrats (Birkland, 2014). For example, over the years, a body of 'street level business advisers' materialised who 'provide services based on their own personal experience and expertise, create bespoke and area-specific services that varied in mode of delivery and nature from Business Link to Business Link' [when Business Link was in existence] (Atherton et al, 2010, 258). Moreover, Mole $(2002,191)$ states that 'business advisors have the technical expertise and closeness to delivery that enables them to modify small business policy.' This suggests that much of the enterprise policy process, in 
particular its implementation, appears disconnected from activities i.e. business support and to what is actually delivered to entrepreneurs and to SMEs. As such, these approaches to the implementation gap can be explained by the different levels of power held by different groups of actors involved. It is important then to ask, what relationships exist between the different actors both in the top-down and bottom-up approaches? Without understanding and addressing these gaps, the ability to learn from the policy process of design and delivery becomes weakened, and future enterprise policy initiatives and implementation practices are undermined.

There is mounting evidence from academic studies and government reports which argue that the implementation gap within the enterprise policy process exists which can lead to the ineffectiveness of enterprise policy or even to its failure (Gilg and Kelly, 1997; Gibb, 2000; Roper and Hewitt, 2001; Smallbone and Welter, 2009; Cabinet Office, 2015). Whilst implementation is often referred to as having a 'gap' whereby the operationalisation of such policy initiatives causes policy ineffectiveness and failure, this may also arise from the 'attempts to transfer standardised practices that are not necessarily universally applicable' (Atherton and Price, 2008, 368). The transferability of policy initiatives is often difficult given the context of local economies and political conditions, because generic enterprise policies being transferred across Europe have proved to be ineffective as local contexts and practices have not been considered (Neuwalaers and Reid, 2002; Atherton and Price, 2008). 


\section{Methodology}

\subsection{Sampling}

The study uses a qualitative approach based on a total of 21 in-depth semi-structured interviews with three different groups of individuals: eight policy-makers within a government department, four senior managers from an RDA and nine senior business development managers at various local enterprise agencies in the region. The selection of participants was underpinned by 'a conceptual question, not by a concern for representativeness' (Miles and Huberman, 1994, 29). As such, the major concern was how enterprise policy was implemented, hence the interviews needed to comprise of people involved in the process. Individuals were selected via purposeful sampling, a technique widely used in qualitative research for the identification and selection of information-rich cases (Patton, 2002). This enabled the researcher to ascertain the appropriateness of potential participants for the study and to 'show different perspectives on the problem, process or event I want to portray' (Creswell, 1998, 62). Purposive sampling represented a commitment to interviewing people who had experience with, or were part of the culture or phenomenon of interest (Speziale and Carpenter, 2003). Access to the interviewees was granted on the condition of anonymity. The experiences and discussions were based around a policy document, Enterprise: Unlocking the UK's Talent (Department for Business Enterprise and Regulatory Reform, 2008), which at the time of the study was the most important and relevant document from which enterprise policy initiatives were implemented across England.

Building on the purposive sampling strategy, intensity sampling was used for selecting participants. Intensity sampling allows 'excellent or rich examples of the 
phenomenon of interest, but not highly unusual cases...cases that manifest sufficient intensity to illuminate the nature of success or failure' (Patton, 2002, 234). This type of sampling required the researcher to have prior information on the variation of the phenomena under study in which all participants were involved in the implementation of enterprise policy. The eight senior policy-makers who were interviewed were highly knowledgeable informants who viewed the focal phenomenon from diverse perspectives (Eisenhardt and Graebner, 2007), and were working at both national and regional levels. The RDA in central England was also selected via this sampling, as were the business managers with the local enterprise agencies, all of whom were accessible and known to be 'experts' in the field of study that was being undertaken. The selected RDA was, at the time, involved in enterprise policy with respect to implementing and advocating the importance of enterprise within their region. The four interviewees selected from the RDA had working relationships with the government department and played an important role with respect to the enterprise agenda. The individuals were also involved in the delivery of enterprise policy initiatives to local agencies, and the evaluation and reporting aspects of the policy delivery. The business managers were from the local enterprise agencies, the same geographical region as the RDA, allowing an understanding of their relationship. The nine agencies chosen for the study all offered business support to individuals within their local areas. They were chosen by their area through internet searches and via the local council website.

The advantages of purposive sampling is that it allowed the researcher to interview people and understand events grounded in what they believe (Dane, 1990). Rather than advocating typical instances, a cross-section or a balanced choice, it allowed concentration on instances which displayed a wide variety, focussing on extreme cases to illuminate the research questions at hand. The goal was to develop a rich and dense description of the culture and phenomenon rather than just results that support the generalisability of the 
findings (Speziale and Carpenter, 2003). However, as with every sampling method there are also disadvantages. Purposive samples are small and cannot be widely generalised and also they are not easily defensible as being representative of populations. Nevertheless, the use of purposive sampling led to an active search to enrich data by including participants who have a particular type of experience, characteristic or understanding to share (Macnee and McCabe, 2008).

The names of the interviewees are not disclosed in order to protect their anonymity and confidentiality. Policy-makers are abbreviated to PM, while the level of seniority held by each relevant interviewee is illustrated by the addition of JM, MM or SM, denoting respectively Junior Management, Middle Management and Senior Management. The interviewees for the local enterprise agencies and the RDA are denoted by their initials and their job titles (Figure 2).

\section{INSERT FIGURE 2 HERE}

\subsection{Data collection}

A set of theoretical and historical questions about the nature, causes and consequences of enterprise policy, an important but poorly understood large-scale social transformation, informed the interview guide (May, 2002). The interviews were centred on Lundstrom and Stevenson's (2001) interview guideline from their study of entrepreneurship/SME policies in ten different economies. Lundstrom and Stevenson's (2001) interview had three main sections: definition and data; objectives, policies, programs and structure; and SME/entrepreneurship focus. These themes were broadly taken into consideration when preparing the interview guides. For each different interview group, there were similar themes 
including objectives; policies, programmes and structure; SME/entrepreneurship focus; implementation; relationships; and challenges. Crucially, the interview guide was tailored to each group. Table 2 shows the themes within the interview guides. Each theme is inherently inter-dependent and reliant on each other for the process of enterprise implementation to be undertaken. Hence respondents needed to understand the objectives, policies, programmes and structures of what was being implemented; whether there was an entrepreneurship and/or SME focus dependent on the aims; how the process of implementation was undertaken; the actors involved in the process and their relationships; the perceptions and experience of what was being implemented; and finally, the evaluation of such initiatives to understand whether they have been effective or not.

\section{INSERT TABLE 2 HERE}

Four pilot interviews were undertaken with a senior academic (an expert in enterprise policy), a policy-maker, an RDA member of staff, and a local enterprise agency - individuals who had similar interests as those who were participating in the research (Patton, 2002). This allowed for any refinements required to the interview questions before undertaking the data collection (Miles and Huberman, 1994; Kvale, 2002). Interviews, lasted between 90 to 120 minutes, were recorded and transcribed verbatim.

\subsection{Data analysis}

The data analysis involved four steps (Miles and Huberman, 1994). The first step was to transcribe the interviews after each interview. Field notes and memos were carefully filed and subjected to analysis at a later point to allow the triangulation of methods to strengthen the validity and credibility of the research. The second step required the confirmation and 
familiarisation of the interviews. Interviewees were sent their transcript via email and afforded the opportunity to confirm the accuracy or to make appropriate amendments (Fine et al, 2010). Following confirmation, the interview transcripts and field notes were re-read while initial comments were noted in the margins (Patton, 2002). This inductive analysis allowed for themes and codes to emerge, providing the opportunity to start organising, structuring and making sense of the raw data.

The third step involved data reduction, defined as 'the process of selecting, focusing, simplifying, abstracting and transforming the data' (Miles and Huberman, 1994, 56). Although data reduction is important, this process was present throughout the entirety of the analysis process. Analysis was conducted during and after the interview process which enabled the themes to be developed in more depth during the interviews (Silversides, 2001). This process began to generate a greater understanding of the research problem and to encourage the researcher to seek meaning from the phenomenon allowing this stage to guide the research (Carson et al, 2001). An initial list of codes was identified, and a template which represented themes and patterns emerged from the textual data as a means of interpreting text with the aid of template analysis (King, 2012).

The final stage involved coding and interpreting through the use of NVivo (Fereday and Muir-Cochrane, 2008). This aided re-examination of the data, re-coding it where necessary and linking key concepts as patterns until relationships among emerging categories of data became obvious (Marshall and Rossman, 1995). The template allowed a coding scheme where codes were arranged in a hierarchical fashion depicting the relationship between themes, with the broadest at the top, and more specific second or third tier subthemes descending from each. All codes were named and given an individual 'node.' NVivo nodes conform to a tree structure with categories overarching the different concepts dividing them into sub-nodes as appropriate. The most relevant nodes are 'tree nodes' which were 
used to capture the essence of the data being analysed. The nodes were subsequently assigned a word relevant to their respective properties. In total, there were 37 tree nodes with each dividing into sub-nodes. The purpose of this stage of analysis was to ensure that the findings which had emerged in the first round of coding could be systematically evidenced in the data, thus addressing the issue of validity. Analysis began by identifying a priori themes relevant to the research which NVivo established through guidance from the literature as well as from themes that were used to structure the interview guides. These themes were 'provisional' and 'open to modification' following successive readings of the text (King et al, 2002, 334). The final template was, as is the case in most research of this form, the product of a long and iterative process which required continuously moving back and forth between the text, coding, sorting, making connections and presenting the results (Crabtree and Miller, 1999).

To ensure content reliability and to avoid researcher bias, triangulation and respondent validation were included in the research design. Triangulation involved obtaining as many different perspectives on the data as possible, in this case policy-makers, RDA staff and local enterprise staff were interviewed to bring different perspectives. Data from multiple informants, organisational documents, secondary published materials and outsider perspectives were all reviewed with respect to ensuring the validity and reliability of the data collected (Fine et al, 2010). Respondent validation involved allowing participants in the research access to their transcripts and the data collected to ensure that their input and their evaluation of its authenticity to correct researcher bias (Lincoln and Guba, 1985).

\section{Findings}

Figure 3 provides a structure for the discussion of the findings and allows an understanding of the process of enterprise policy implementation. First, it describes how each of the actors 
understood the implementation of enterprise policy process. Second, the delivery of enterprise policy initiatives is investigated. Third, the evaluation of enterprise policy initiatives is explored. Finally, the relationships between all those involved are discussed. The quotes highlighted within the findings are the most demonstrative of the research findings (Patton, 2002).

\section{INSERT FIGURE 3 HERE}

\subsection{Understanding the enterprise policy implementation process}

It is important to understand how the policy-makers, the RDA managers and the business managers at the local enterprise agencies viewed and understood the implementation of enterprise policies. The implementation phase of enterprise policy initiatives is relatively unknown. The policy-makers interviewed recognised the implementation framework for delivering enterprise policy initiatives as clear and explicit. A senior policy-maker described the implementation of enterprise policy:

\footnotetext{
We've got a well-defined project plan for implementing the enterprise strategy which has got an analytical strand, it's got a communication strand, and it's got a policy delivery strand. In our analytical strand of implementing enterprise strategy we're developing detailed objectives and have monitoring and evaluation plans for each, not every single little initiative within the enterprise strategy but for the most important ones (PM1:SM).
}

The portrayal of the process addressed three elements: analysis, communication and implementation. However, this description was vague in establishing how enterprise policy was implemented. The emphasis was placed on the RDA within the region to deliver the 
policy initiatives in a timely manner and in alignment with their Regional Economic Strategies (which set out key challenges and economic development priorities for each RDA region). The policy-makers recognised that the RDAs had targets to meet in delivering policy initiatives:

\begin{abstract}
The high level of context set by central government in each region is a thing called RES, the Regional Economic Strategy, at a higher level context, it needs to be reflected in the economic strategy and beneath that there will be implementation. So that's more or less the delivery method (PM2:JM).
\end{abstract}

Although enterprise policies came from the government to RDAs there was a sense of collaboration in ensuring that the initiatives were implemented:

\footnotetext{
We've got different levels; ministers meet with RDA chairs and RDA chief executives on a regular basis. That will obviously be much broader around the economic strategies that the RDAs have got responsibility for delivering but part of the agenda will be on implementation of the enterprise strategy. At working level our directors meet with their equivalents at the RDAs to discuss progress on individual programmes, projects or schemes. As you can imagine the reality is that there is a lot of toing and froing to try and make that work (PM8: SM).
}

The consensus from the policy-makers therefore highlighted a simple process with collaboration in implementing enterprise policy initiatives. In contrast, the RDA interviewees described a series of challenges which they faced when implementing enterprise policy initiatives from the White Paper 'Enterprise: Unlocking the UK's Talent' (Department for Business Enterprise and Regulatory Reform, 2008): 
I think it was just launched. I don't think there was any communication. It was just publicly launched and at the next chief's meeting it was discussed how RDAs could take it forward but nothing more than that. Then our boss came back and said we have to do some of these things (DH, RDA).

It was just the document and then off you go. My boss and the Corporate Director went to a meeting, they were being micro managed at that stage. It was a basic case of no more resources; it wasn't a new intervention, just get on and do it. A lot of things have fallen by the wayside because they were just ideas that were never thought out properly (DH, RDA).

Central government will give RDAs targets and RDAs are the contract holders. They are told you have got to support this many businesses and this is what we want and then RDAs put out a tender...then those work streams are given to those who can be successful bidders for delivering and then they deliver. Then they say this year we are going to support so many businesses and we are going to deliver this service...they deliver that either themselves or with partnerships with delivery intermediary organisations (MR, RDA).

It would therefore appear that were no formal guidelines or frameworks for how the RDA should implement enterprise policy initiatives. Despite, the collaborative efforts mentioned by the policy-makers there was little knowledge transfer among the actors delivering enterprise policy initiatives. As a consequence individuals could not explicitly discuss the implementation process because they themselves were uncertain, illustrating ineffectiveness:

\footnotetext{
It's not too difficult to create policy as such but then to take it the next stage is a big problem and can take time, going through all the different mechanisms and processes to get something before we can do a project or a programme. So sometimes by the time something gets off the ground it can become outdated (DB, RDA).
} 
The local enterprise agencies managed the final transition of enterprise policy into deliverable outcomes. They too were confused about how they should be delivering such initiatives:

It's like Chinese whispers (PH, Local Agency).

\begin{abstract}
As soon as the policy is out they want the support to be in place straight away and when you look at the nature of the beast in delivery and look at the different regions, different agendas, you can't do that (AR, Local Agency).
\end{abstract}

\begin{abstract}
If there are new initiatives as far as enterprise contracts are concerned anyone can get involved, I would be notified on the supply2gov website, so it's not necessarily through Business Link. Although Business Link have some information on their website but it doesn't necessarily get sent to everyone (SB, Local Agency).
\end{abstract}

It is therefore clear that the transition of policy initiatives into deliverables from the government department and the RDA to local agencies was very ad hoc with little direction. There was no mention of a national framework in place. Consequently local agencies resorted to foraging through various websites and other sources for information to understand how and what policy initiatives would be implemented. As a result, implementation was interpreted differently by the individuals involved in the process. This process has shown little improvement under the LEPs because currently there is a mismatch in the demands of SMEs and entrepreneurs and the activities which LEPs are delivering because the business community is under-represented within LEPs (Marlow et al, 2013).

At a national level it was assumed that implementation was a formal process. However, the reality was that regional and local agencies held various ideas about what to deliver and how, and therefore adapted policy initiatives in diverse ways. At a regional level 
implementation was deemed to be dependent on being seen to be 'doing something' and at the local level there was little support and assistance from national and regional levels in the implementation process. At each level, the implementation of policy initiatives was both confusing and convoluted with many of the actors involved having little knowledge of the process. This confirms the existence of a clear 'implementation gap' arising between the stated policy objectives and the practice of delivering them (Smallbone and Welter, 2009).

\subsection{Delivering enterprise policy initiatives}

The main goal of implementing enterprise policy initiatives is to deliver effective business support to SMEs and entrepreneurs (Greene and Patel, 2013). There were a number of challenges. The first issue was the fragmentation of the process. PR (RDA) was of the opinion that business support was disjointed in terms of delivery. PR (RDA) argued that very little had changed over the years - there were more business support programmes available and more delivery organisations, but little impact was evident. Given this, business support has often had low take-up rates (Robson and Bennett, 2000) and:

\footnotetext{
It could be that what you're doing just doesn't appeal to the people that are not using the services or that they know about them, they don't like them, they will never come forward to use them as they have a perceived or a reality that they're rubbish and that they don't want anything to do with them (PM6:JM).
}

The second issue raised was the complexity of business support. The local agencies voiced their frustration at the demands of delivering enterprise policy initiatives from the White Paper. DH (RDA) expressed dissatisfaction with unnecessary duplication with previous initiatives. It was unclear whether there was a need for a White Paper and to what 
extent it brought 'newness' and effectiveness to existing support. PM8:SM also raised the issue of wasted skills and resources emanating from the current system and leading to poor delivery. JW (Local Agency) went so far as to claim that corruption was prevalent in the delivery of business support:

\footnotetext{
I think you know in terms of cutting a lot of waste, there's a lot of corruption going on with business support and I think the government is right to say we have to stamp out the corruption because a lot of public money is being wasted and people playing the system.

I think that a lot of the money that goes to some of the delivery agents with regards to supporting businesses doesn't necessarily get to the right people in the right way (AR, Local Agency).
}

These comments drew attention to the issues surrounding business support. An underlying explanation could be that a problematic relationship exists between those implementing policy and those utilising the initiatives because they each have differing ideals and expectations. There have been concerns and criticisms of LEPs surrounding the lack of business engagement between themselves and SMEs and entrepreneurs (Thompson et al, 2012).

The final issue that arose in terms of business support was how national aims and objectives were interpreted, and how this subsequently influenced the delivery. For example, PM7:MM alluded to the largely ineffective delivery of business support, citing the White Paper - a case where the RDAs and the local agencies were asked to download the White Paper, interpret it and implement 'something and anything' from the Paper before reporting back to the government department with which policy initiatives would be delivered. This highlighted that there was no formal indication or support to what should be delivered in accordance to the agency resources and the local needs. Little seems to have changed in 
recent times, a key barrier in delivering enterprise policy initiative includes LEPs having a lack of skilled workers to deliver policy initiatives (Pugalis and Townsend, 2015). Furthermore, LEPS have limited delivery powers in comparison with their predecessors, the RDAs (Pugalis et al, 2012).

In summary, the implementation of enterprise policies in England have been adversely impacted by several factors: the fragmentation of service delivery organisations, making it difficult to control the direction of implementation, wasted resources and the lack of understanding of what support initiatives should be delivered.

\subsection{Evaluating enterprise policy}

Government departments abide by the ROAMEF cycle (Rationale, Objectives, Appraisal, Monitoring, Evaluation and Feedback) which provides not only a blueprint on how policy should be formulated and implemented, but also makes explicit reference to an evaluation stage (HM Treasury, 2005). Policy-makers did not make reference or acknowledge the ROAMEF cycle during the interviews. PM6:JM noted that because of the limited resources available to gather evidence there was no viable means to determine the outcomes of enterprise policy initiatives. A monthly tracking spreadsheet was used by both the RDA and the local enterprise agencies to compile relevant data and track progress. Information such as how many businesses were looking for advice, what type of advice, etc. was recorded. Monitoring and measuring involved reporting back to the government department on a monthly basis to justify the RDA and local agency funding allocations. This was neither a formalised, nor sophisticated means of measuring policy effectiveness. Rather, the enterprise policy initiatives were 'measured in a kind of ad hoc way' (PM7:SM). The 
policy-makers argued that they had stringent evaluation and measuring techniques in place but in reality the evaluation of enterprise policy initiatives was clearly different:

I'm not sure that there are any measurements in place (PM7:SM).

To the extent that measurement of enterprise policy initiatives occurred, it was volume based - survival rates, start-up rates, jobs created - and the overall primary measure of success was gross value added (GVA). This highlighted that Storey's (2002) six steps framework was not considered for enterprise policy evaluation. There was a desire to meet targets rather than necessarily provide the fundamentals of business support and advice to those who required the assistance. DB (RDA) argued that the evaluation methods employed lacked an understanding about what it meant to monitor and evaluate programmes within the public sector. The onus was on headline-grabbing figures without much concern regarding to how, when and where evaluation would take place:

\footnotetext{
The focus of government is all achievement of large numbers and government communicating headlines. So this is a sound bite world and I understand why that's the case and it's certainly the case in the business support world but it doesn't leave much opportunity to be able to focus on the delivery of measurable outcomes for the businesses we work with (AW, Local Agency).
}

I think in a fairly crude way, number of businesses started and the gross value added and all these strategic added values, again I think you know how those measures get translated is not a process that's been thought through that well because do we want $\mathrm{X}$ number of business starts but what about the quality of those businesses, what about the sustainability of those businesses? (MR, RDA).

Concerns were also raised by the RDA as to whether local agencies could adequately measure the outcomes of enterprise policy initiatives in the very short time scales set: 
Measurement of activity as a proxy for outcome is relatively easy to do and easy to achieve and easy to give them the numbers. And then they can be satisfied that we are achieving the volumes of activity but that really isn't the benefit, the benefit invariably lags the activity by 12 or 18 months, maybe longer. Unfortunately, for government that's too long a lag and they want to know what we're doing with their money and want their returns in a relatively short period of time. Therefore, you're forced to measure that return by short-term activity measures as opposed to longer term economic benefits (DB, RDA).

The lack of stringent evaluation and monitoring of enterprise policy initiatives led to little, if any, general knowledge in how implementation was undertaken. Evaluation and monitoring are part of the formulation and the implementation process, but neither was considered by the national, regional or local actors involved as an important part of the overall framework of the enterprise policy process. This seems to have continued with the LEPs, since only $11 \%$ of LEPs have commissioned an evaluation of their impact (Federation of Small Business, 2014). It is important to understand and undertake evaluation, even in its most basic form to ensure value for money where issues of accountability and the opportunity cost of spending public resources are taken into account (Lenihan et al, 2005; Peck et al, 2014).

\subsection{Relationships between government, regional agency and local agencies}

The relationships between government, the regional agency and the local enterprise agencies were dominated by contractual agreements with targets set by government at a national level. However, these targets were allocated without any additional support (i.e. funding) which led to trade-offs with respect to what to deliver and how. LEPs are currently encouraged to leverage private investment rather than relying on central funding and have in the past bid for 
funding (for example the Regional Growth Fund) (Ward, 2014). However, in the time of the RDAs implementing initiatives with inadequate resources was common procedure:

\begin{abstract}
The challenge at the moment is that there is a mismatch in the way government hand down those messages to regional government and how they then enforce them and because government has pulled resources away from Regional Development Agencies a lot of the RDAs are not spending what they need to spend on enterprise (PM3:MM).
\end{abstract}

By virtue of the lack of resources available, targets and meeting contracts for RDAs and local agencies remained the same. PM3:MM regarded the meeting of targets by RDAs as a choice best suited to their regions:

\begin{abstract}
It's certainly always been the case that the relationship between central government and the RDAs has been a difficult one because of the power struggle, RDAs need to use the funds allocated by the government that they think they believe suit the circumstances of their own region and sometimes regions will prioritise one policy over another. So it's not an easy relationship and I think it works better in some regions than in others.
\end{abstract}

It is clear from PM3:MM's statement that policy-makers were not involved in the implementation of enterprise policy initiatives. The demands of delivery were therefore placed on the RDAs and the local agencies but without any discussion as to whether implementing such enterprise policy initiatives were feasible or, indeed, realistic given the available budget. Rather:

\footnotetext{
It's become very top-down and their [local agencies] required to do so much to meet contractual needs of RDAs and also the needs of government (PM4:MM).
} 
The final strand of the policy involved the local enterprise agencies who were charged with executing enterprise policy. Although the local enterprise agencies interviewed argued that they had strong and positive relationships with their RDA and other local agencies, they regarded such relationships as merely contractual. SB (Local Agency) alluded to a 'fundamental disconnect' between the local agencies and the RDAs. As a consequence, local agencies were not involved in the discussion of what enterprise policy initiatives were delivered and how. Table 3 identifies some of the more pertinent quotes from the local agencies with respect to the relationships between the different groups of organisations involved. Further to this, the lack of government support for LEPs has resulted in delays, inhibited the coherent communication of local growth policy to business and acted as a barrier to business engagement. It was noted that small businesses and entrepreneurs are less likely to be engaged with LEPs because of such challenges (Marlow et al, 2013). Furthermore, there has also been friction between government and LEPs where governance arrangements, transparency, accountability, and the role of stakeholders has caused tensions to rise (Federation of Small Business, 2014).

\section{INSERT TABLE 3 HERE}

When probed further, many of the local agency representatives argued that there was little room for negotiation with respect to targets. A widely held opinion amongst the local enterprise business managers was that RDAs were a hindrance, imposing a further layer of bureaucracy with no obvious benefits. Prior to the creation of the RDAs, the relationship between central government and local agencies was one of direct engagement. It was claimed that RDAs imposed a top-down structure and often it was a case of 'follow the money, follow the contract' (PM5:MM). 
Policy-makers pushed for a formal relationship with the local agencies to better understand the work being undertaken. Local agencies also showed an interest in becoming involved in the policy-making decisions. However, structures were rigid with many obstacles preventing local agency involvement. PH (Local Agency) commented:

\begin{abstract}
I would look to central government to set a framework and then I would let the interpretation of that framework happen and now I just don't think it's done as well as it could be. Whether that's to do with too many constraints, or whether the government is too prescriptive, whether there isn't the talent locally to do that, I don't know but I think it's the fact that everybody is so busy down here and trying to respond to every policy document that we actually all lose sight of what we are doing.
\end{abstract}

The local agencies operated with some degree of freedom in respect to how they achieved their outputs, but the targets remained the same. In turn, the RDA had the authority to exercise their capacity to reduce contracts and impose penalties if targets were not met. There were, thus, unrealistic expectations placed on those implementing enterprise policy initiatives. The process was equated to a box ticking exercise where the actors often lost sight of what they were trying to achieve:

\footnotetext{
The problem is that you can spend your life ticking boxes and achieving outputs when the real issues are with the clients (JL, Local Agency).

The RDA can tick the box it's working with minorities but it's not achieving a good outcome from ethnic minority businesses, so to some extent there might be similar issues with gender and other diverse groups as well (MR, RDA).
}

Although previous arguments state that enterprise policies should seek to encourage diversity and experimentation across regions (Gibb, 1993), the government department did 
not acknowledge regional diversity. It has been argued that regional differences are important because regions can influence enterprising activities (Huggins and Williams, 2011; Williams and Vorley, 2014). However, because national goals were inherently different from individual regional targets, this meant that the policy aims at national level were unclear to regional agencies.

All of this was underpinned by the further problem that the communication from national to regional and local levels was dysfunctional and beset by poor network linkages. This resulted in sizable gaps in implementation at important stages of the process. Communication between the government department and the RDA was based around deliverables, with significant weight attached to quantifiable objectives. The quantitative nature of capturing the targets failed to adequately evaluate and measure the implications of the policy initiatives being delivered (Vega et al, 2013) because often it was highlighted by the RDA that:

\footnotetext{
We've got quite a lot of work to do to come up with mechanisms for making sure that at the highest level the government gets the figures that it needs (DH, RDA).
}

Again the emphasis of the relationship between government and the RDA was placed on targets rather than the quality of support and advice being delivered:

\footnotetext{
I think they [government department] pay too much attention to targets. I don't think they make the connection between outcomes, process and context (MR, RDA).
}

I think that the majority of government programmes are output driven, (rather) than having any impact (PR, RDA). 
An important factor influencing the willingness of the agencies to implement public policies was the conflict of actors both at top-down and bottom-up levels, identified previously by Tummers et al (2012). The relationship between the actors at the national, regional and local levels illustrate that enterprise policy implementation problems derive not simply from flaws in its design, but also originate from the policy's relationship to its institutional setting (Berman, 1978). As such, there were no direct procedures, funding or reporting mechanisms in place to allow for a smooth transition of delivering enterprise policy initiatives. In turn, this heightened the tension between the different groups of actors when it came to implementing enterprise policy initiatives. The evidence indicates that although enterprise policy initiatives were announced for delivery, those involved had little knowledge of the process of implementation itself or ways to achieve the most effective results required. The relationships between the different groups have offered an insight into the dynamics amongst those involved in the implementation of enterprise policy. The links were distant and reserved in a stringent top-down formation from government to local agencies often leading to haphazard delivery of enterprise policy initiatives.

\section{Conclusion}

Enterprise policy has been criticised for its lack of effectiveness (Storey and Greene, 2010). The debate on the reasons for this has largely focused on its objectives and design (e.g. Shane, 2009; Arshed et al, 2014). However, this paper turns the focus on enterprise policy implementation. Its purpose was not to 'correct' the policy or the assumptions behind it - if the policy itself is wrong, addressing the challenges of implementation may still lead to ineffective policy. Rather this study explored one of the many reasons why enterprise policy is ineffective whereby the focus lies in the implementation stage. It provides evidence to 
support the argument that the implementation stage of enterprise policy is a potential root cause of its ineffectiveness.

Several factors have contributed to the poor implementation of enterprise policy which, in turn, has impacted its effectiveness. Firstly, the lack of guidance from policymakers and government procedures in the implementation of enterprise policy initiatives led to a poor understanding by RDAs and local enterprise agencies about what they should have been delivering and how. Secondly, emphasis was placed on fulfilling contractual duties rather than on delivering high quality business support and advice. For funding reasons contractors tended to follow the letter, rather than the spirit, of the contract. Thirdly, measurement and evaluation of the impact of enterprise policy initiatives was rudimentary and lacked any form of in-depth evaluation leading to virtually no feedback loop as to whether the initiative required changes, and if so, how and why. Little importance was placed on the businesses and their owner-managers, with all efforts directed at meeting targets so as to ensure avoiding detrimental impacts to RDA and local enterprise agency funding. Finally, relationships between national, regional and local actors were fragmented and fraught with difficulties. The actors at each level did not know what was being delivered, how and to whom. This was often because of the speed at which they were asked to deliver enterprise policy initiatives.

The findings highlight that enterprise policy only appears to exist at the macro-level (top-down). Once enterprise policy initiatives are finalised for delivery via the local agencies at a micro-level (bottom-up), policy has changed its focus to meeting targets. This has led to ineffective outcomes, wasted financial resources, and potentially a disillusioned community of entrepreneurs and SMEs. The emphasis was placed on the 'street-level bureaucrats' to ensure delivery of enterprise policy initiatives but numerous issues hindered effective implementation (lack of formal structures for implementation, complex relationships etc.). 
The minimal contact and lack of formal procedures between top-down and bottom-up participants in the implementation process of enterprise policy highlights the limited flexibility of what is delivered and how. No importance was placed on whether external expectations were met or whether entrepreneurs and SMEs were given appropriate support and assistance to start-up and grow (Vega et al, 2013).

In practical terms, our findings offer a number of recommendations for improving the implementation of enterprise policy. Given the informal process under which the implementation of enterprise policy is undertaken, a national framework for the delivery of policy initiatives is needed. A national framework would assist enterprise agencies in delivering at their optimum level in accordance with the needs of their local entrepreneurs and the SME community, rather than simply meeting targets set at a national level. This could be achieved by giving LEPs the responsibility to manage their own funding streams and be empowered to demonstrate greater flexibility on how they design and deliver programmes (Confederation of British Industry, 2012). LEPs are more locally focussed on economic development and redevelopment 'with an assumption of the hegemony of public sector institutions, democratically mandated, implementing and delivering public services' (Fenwick et al, 2012, 408). This localised approach would allow the government to become more proactive in understanding what is happening 'on the ground'. One of Lord Heseltine's recommendations from his report, No Stone Unturned: In Pursuit of Growth (2012) further highlighted a greater devolution of funding from central government to LEPS, to ensure that economic development was tailored at a local level. However, it has been argued that LEPs have not been given the powers and resources to efficiently undertake this recommendation and concerns have been raised with respect to accountability and capacity to deliver (National Audit Office, 2013; Federation of Small Business, 2014). 
The significance of this potential shift in the implementation of enterprise policy would have a knock-on effect on the relationships between the actors involved, embracing both top-down and bottom-up approaches. Strategies for developing enterprise policies that incorporate and guide contributions from policy-makers, delivery agencies, academic researchers and the business community are encouraged (Thompson et al, 2012; Woods and Miles, 2014). Exploring the macro (government), meso (enterprise policy initiatives) and micro (delivery agencies) within top-down and bottom-up approaches would result in sharing responsibilities and empowering local level stakeholders with the flexibility to deliver what is needed in their local area, as opposed to what government thinks is needed. This, in turn, will produce a higher quality of delivery of enterprise policy initiatives.

Furthermore, in terms of setting up a national framework, each area or LEP would be required to address the needs of their local entrepreneurs and SMEs rather than delivering enterprise policy initiatives chosen at randomly from White Papers. The regional approach has been criticised for failing to 'identify issues for which there is significant differentiation across regions, with regional planning guidance tending to replicate national policy rather than translating it into a regional context' (Huggins et al, 2014, 3). This would also allow for regular monitoring and evaluation of policy initiatives, not only to develop a better understanding of their influence and impact but also to address the need to benchmark and to assess the wider impact. Formal measuring and evaluating mechanisms should be incorporated at the formulation stage. These mechanisms would have the capacity to measure medium-term and long-term objectives, possibly using Storey's (2002) six steps, rather than only capturing a snapshot of the short-term outcomes (Roper and Hewitt, 2001). Evaluation of enterprise policy is fundamental to the development and assessment of rationales for business support, hence building an evaluation culture can effectively determine impacts and results (Lambrecht and Pirnay, 2005; Cairney, 2009). However, consideration should also be 
given to assessing the wider impacts of enterprise policy initiatives, for example, the effect on mind-sets, culture, changes in gender, ethnic minorities etc. This would allow policy-makers to understand the heterogeneity of the business community.

The enterprise policy process presents new challenges for future research given this study. Evidence is required to understand how the implementation process has changed and whether this has had an impact on the delivery of enterprise policy initiatives. A better understanding of the actors and the process within the overall enterprise policy framework is essential. Key actors include those both at top-down and bottom-up hierarchies where ministers, senior civil servants, policy-makers, business development managers and, entrepreneurs and SMEs are key in influencing what is delivered and how. A synergetic relationship between these actors is required whereby agreement over priorities and realistic outcomes are discussed. This allows an understanding of the complexities of the policymaking process.

Since the conclusions drawn are from a limited temporal period against the background of one political administration a good starting point for future research would be to explore the implementation process under different governments in different countries and institutional arrangements. While this paper offers insights into the implementation of enterprise policy in the context of England, similar studies across global governments would provide a comparative understanding. Previous studies have highlighted the implementation of enterprise policy in different contexts. For example, Batterbury's (2002) study of evaluating enterprise policy implementation in Galicia and Sardinia highlights the importance of local conditions for effective policy implementation. Furthermore, Niska and Vesala (2013) study the relationship between the actors who implemented SME policy and the entrepreneurs in Finland. The findings highlight that there was conflict between both parties as to what was being delivered and who the more important of the two was with respect to the 
policy being delivered. Cuckovic and Bartlett's (2007) study of SME policy highlighted the main difficulties to effective policy implementation and the role that the Europeanisation of policy can play in improving the process of policy implementation. Closer to home, Vega et al's (2013) study in the North West of England shows that enterprise policy statements should be reframed and evaluation should be seen as a learning process both for policy programme successes and failures.

However, this study is not without its limitations. Generalising from this study should be made with caution. Since the study was undertaken, the government has changed twice. With new governments come new ministers, cabinet shuffles, and civil servant and policymakers being allocated new roles and teams. Although it is unknown at this early stage how enterprise policy is being undertaken under the new government, the evolving political and economic environments need consideration. However, this does not prohibit the replication of this research under a new government, with either the same department or across different government departments to understand the current state of play with respect to the enterprise policy process. A further limitation of the study is that the focus was on policy implementation in broad terms, rather than on one specific enterprise policy or initiative. This arose from anonymity and confidentiality agreements which would have been breached had a specific enterprise policy initiative been discussed.

A final limitation of the study is that only one part of the enterprise policy was studied and explored - the implementation stage. The formulation of enterprise policy has previously been explored by Arshed et al (2014) who argues that the policy process is not a piecemeal or step-by-step process rather it is probable to be seen as a continual, iterative process, which is unlikely to be ordered in a sequential fashion (Cairney, 2009). A more informed and holistic approach to understanding why enterprise policy is ineffective needs to be explored. 
The ineffectiveness of enterprise policy has been shown to lie not only in its formulation (Arshed et al, 2014) but also in its implementation. In opening up the 'black box' this paper shows that the process of translating enterprise policy from policy-makers to delivery bodies has also had adverse effects on its effectiveness. The evidence highlights that the implementation process is complex, fragmented, unpredictable and weak. By focusing on this part of the policy process, this paper has provided new insights and opens new challenges for future research of enterprise policy. 


\section{Notes}

1. Initiatives within this study refer to the actual instrument that is being delivered or implemented by agencies (either private or public) to meet a goal. Enterprise policy initiatives can be grouped broadly under a number of areas: access to finance, tax reliefs and discounts, funding, advice, networking and collaboration, and skills (Centre for Cities, 2013). For example, specific initiatives under enterprise policy include GrowthAccelerator, apprenticeships, etc.

2. Although, the SME sector saw an increase of 1.1 million $(31 \%)$ of private sector enterprises between 2000 and 2011 (Department for Business Innovation and Skills, 2012) with 5.2 million small firms currently in the UK (an increase of 760,000 since 2010) (Lord Young, 2015), these figures cannot be attributed to government intervention (Pickernell et al, 2015). The issue also highlights that entrepreneurs and SMEs are not in favor of taking up such support and often prefer private providers of support (Loader, 2013; Jones et al, 2013).

3. The delivery of enterprise policy refers to the process whereby initiatives are implemented to the entrepreneurs or to the SMEs to ensure goals are met to increase business start-ups and business growth.

4. RDAs were abolished in March 2012 and have been replaced with smaller-scale partnerships between local authorities and businesses, known as Local Enterprise Partnerships (LEPs). The main responsibility of LEPS is to provide strategic leadership in the local areas to measure economic priorities which includes supporting business (Department for Business, Innovation and Skills, 2010). However, the role of LEPs is distinctive from 
RDAs as unlike the RDAs, LEPs do not have responsibilities for inward investment, innovation, and access to finance, which is now controlled by central government (Department for Business, Innovation and Skills, 2010).

\section{Acknowledgments}

The authors would like to thank Professor Hans Landstrom for his constructive comments in helping shape an early version of this paper. 


\section{References}

Acs Z J, Szerb L, 2007, "Entrepreneurship, Economic Growth and Public Policy” Small Business Economics 28 109-122

Anechiarico F, Jacobs J, 1995, "Purging Corruption from Public Contracting: the Solutions are Now Part of the Problem” New York Law School Law Review 40 143-176

Atherton A, Price L, 2008, "Can experiential knowledge and localised learning in start-up policy and practice be transferred between regions? The case of the START network" Entrepreneurship \& Regional Development 20 367-385

Atherton A, Kimo J P, Kim H, 2010, “Who's driving take-up? An examination of patterns of small business engagement with Business Link" Environment and Planning C: Government and Policy 28 257-275

Arshed N, Carter S, 2012, "Enterprise Policymaking in the UK: Prescribed Approaches and Day-to-Day Practice" in Government, SMEs and Entrepreneurship Development Eds R A Blackburn, M T Schaper (Gower, Surrey) pp 61-74

Arshed N, Carter S, Mason C, 2014, “The ineffectiveness of enterprise policy: Is policy formulation to blame?" Small Business Economics 43 639-659

Audretsch D B, 2004, "Sustaining Innovation and Growth: Public Policy Support for Entrepreneurship” Industry \& Innovation 11 167-191

Audretsch D B, Beckmann I A M, 2007, "From small business to entrepreneurship policy" in Handbook of Research on Entrepreneurship Policy Eds D B Audretsch, I Grilo, A R Thurik (Edward Elgar, Great Britain) pp 36-53

Bannock G, 2005, The Economics and Management of Small Business (Routledge, New York)

Barrett S M, 2004, “Implementation Studies: Time for a Revival? Personal Reflections on 20 Years of Implementation Studies” Public Administration 82 249-262 
Batterbury S C E, 2002, "Evaluating Policy Implementation: The European Union's Small and Medium Sized Enterprise Policies in Galicia and Sardinia" Regional Studies 36 $861-876$

Blackburn R A, Ram, M, 2006, "Fix or fixation? The contributions and limitation of entrepreneurship and small firms to combining social exclusion" Entrepreneurship \& Regional Development 18 73-89

Bennett R J, 2006, “Government and Small Business" in Enterprise and Small Business: Principles, Practice and Policy Eds S Carter, D Jones-Evans (Prentice Hall, London) pp 49-75

Bennett R J, 2008, “SME policy support in Britain since the 1990s: what have we learnt?" Environment and Planning C: Government and Policy 26 375-397

Bennett R J, 2012, “Government and Small Business” in Enterprise and Small Business: Principles, Practice and Policy Eds S Carter, D Jones-Evans (Prentice Hall, London) pp 46-77

Beresford R, 2015, "New Labour and enterprise policy: Continuity or change? Evidence from general election manifestos” British Politics $10335-355$

Berman P, 1978, “The Study of Macro and Micro Implementation of Social Policy" Public Policy 26 157-184

Birkland T A, 2014, An introduction to the policy process: Theories, concepts and models of public policy making $3^{\text {rd }}$ edition (Routledge, London)

Blackburn R A, Schaper M T, 2012, "Introduction" in Government, SMEs and Entrepreneurship Development Policy, Practice and Challenges Eds R A Blackburn, M T Schaper (Gower, Farnham) pp 1-17

Bolton J E, 1971, "Report of the Committee of Enquiry on small firms" Bolton Report Cmnd 4811 (HMSO, London) 
Bozeman B, 2013, "What organization theorists and public policy researchers can learn from one another: Publicness theory as a case-in-point” Organization Studies 34 169-188

Bridge S, 2010, Rethinking Enterprise Policy: can failure trigger new understanding? (Palgrave Macmillan, Basingstoke)

Brown R, Mason C, 2012, "Raising the batting average: re-orientating regional industrial policy to generate more high growth firms" Local Economy 27 33-49

Cairney P, 2009, “Implementation and the Governance Problem: A Pressure Participant Perspective" Public Policy and Administration 24 355-377

Cabinet Office, 2015, "Implementation profession: tools for implementing policy", https://www.gov.uk/government/publications/implementation-profession-tools-forimplementing-policy/implementation-profession-tools-for-implementing-policy\#whyimplementation-fails

Carson D, Gilmore A, Perry C, Gronhaug K, 2001, Qualitative Marketing Research (Sage Publications, London)

Centre for Cities, 2013, "Support for growing businesses: A policy briefing”, http://www.centreforcities.org/research/2013/04/23/support-for-growing-businesses/

Confederation of British Industry, 2012, “UK's growth landscape Harnessing private sector potential across the country", http://www.cbi.org.uk/media/1805557/the_uk_s_growth_landscape.pdf

Cowie P, 2012, "SME Policy Evaluation: Current Issues and Future Challenges" in Government, SMEs and Entrenpreneurship Development Eds R A Blackburn, M T Schaper (Gower, Surrey) pp 243-257

Crabtree B F, Miller W L, 1999, Using codes and code manuals: a template organizing style of interpretation $2^{\text {nd }}$ edition (Sage Publications, Thousand Oaks, CA) 
Creswell J, 1998, Qualitative Inquiry and Research Design (Sage Publications, Newbury Park)

Cuckovic N, Bartlett W, 2007, "Entrepreneurship and Competitiveness: the Europeanization of SME Policy in Croatia” Journal of Southeast Europe and Black Sea Studies 737 56

Curran J, Blackburn R A, 2000, "Panacea or White Elephant? A critical examination of the proposed new small business service and response to the DTI consultancy service" Regional Studies 34 181-206

Curran J, Storey D J, 2002, "Small business policy in the United Kingdom: The inheritance of the Small Business Service and implications for its future effectiveness" Environment and Planning C: Government and Policy 20 163-177

Dane F C, 1990, Research Methods (Brooks/Cole Publishing Company, London)

Davies P, 2004, "Policy Evaluation in the United Kingdom", paper presented at the KDI International Policy Evaluation Forum, Korea, May 19-21, 2004

Davies P, 2004, “Is evidence-based government possible?", Jerry Lee Lecture, presented at the $4^{\text {th }}$ annual Campbell Collaboration Colloquium, Washington DC, USA

De D, 2000, "SME Policy in Europe" in The Blackwell Handbook of Entrepreneurship Eds D Sexton, H Landström (Blackwell Publishers Ltd, Great Britain) pp 87-106

de Koning A, and Snijders J, 1992, "Policy on Small-and Medium-Sized Enterprises in Countries of the European Community" International Small Business Journal 1025 39

DeLeon P, DeLeon L, 2002, "What ever happened to policy implementation? An alternative approach" Journal of Public Administration Research and Theory 12 467-492

Department for Business Enterprise and Regulatory Reform, 2008, "Enterprise: Unlocking the UK's Talent" (The Stationary Office, London) 
Department for Business Enterprise and Regulatory Reform, 2010, “Local growth: realising every place's potential" http://www.bis.gov.uk/policies/economic-development/localgrowth-white-paper

Department for Business Innovations and Skills, 2012, "Benchmarking UK Competitiveness in the Global Economy”, https://www.gov.uk/government/uploads/system/uploads/attachment_data/file/34647/ 12-1207-benchmarking-uk-competitiveness-in-the-global-economy.pdf

Doh S, Kim B, 2014, "Government support for SME innovation in the regional industries: The case of government financial support program in South Korea" Research Policy 43 1557-1569

Dorey P, 2005, Policy Making in Britain (Sage Publications, London)

Easton D, 1957, “An Approach to the Analysis of Political Systems" World Politics 9 383400

Eisenhardt K M, Graebner M E, 2007, “Theory building from cases: Opportunities and challenges" The Academy of Management Journal 50 25-32

Federation of Small Business, 2014, “The Future of Local Enterprise Partnerships: The Small Business Perspective Report”, http://www.fsb.org.uk/policy/assets/fsb-making-lepssupport-small-business-better.pdf

Fenwick J, Miller K, McTavish D, 2012, “Co-governance or meta-democracy: Perspectives of local governance 'partnership' in England and Scotland” Policy \& Politics $40405-$ 422

Fereday J, Muir-Cochrane E, 2008, "Demonstrating rigor using thematic analysis: A hybrid approach of inductive and deductive coding and theme development" International Journal of Qualitative Methods 5 80-92 
Fine G A, Morrill C, Surianarain S, 2010, "Ethnography in Organizational Settings" in The Sage Handbook of Organizational Research Methods Eds D Buchanan, A E Bryman (Sage Publications, London) pp 602-670

Friedman R M, 2003 “Conceptual Framework for Developing and Implementing Effective Policy in Children's Mental Health" Journal of Emotional and Behavioral Disorders $1111-18$

Fudge C, Barrett S, 1981, "Reconstructing the field of analysis", in Policy and Action: Essays on implementation of public policy Eds S Barrett, C Fudge (Methuen, UK) pp 249278

Gibb A A, 1993, "Key factors in the design of policy support for SME development process: An overview" Entrepreneurship \& Regional Development 5 1-24

Gibb A A, Haas Z, 1996, "Developing local support services for Small Business Development in Central and Eastern Europe - the donor challenge" Entrepreneurship \& Regional Development 8 197-216

Gibb A A, 2000, "SME policy, academic research and the growth of ignorance, mythical concepts, myths, assumptions, rituals and confusions" International Small Business Journal 18 13-35

Gilg A W, Kelly M P, 1997, "The delivery of planning policy in Great Briain: explaining the implementation gap. New evidence from a case study in rural England" Environment and Planning C: Government and Policy 15 19-36

Greene F J, 2002, “An investigation into enterprise support for younger people, 1975-2000” International Small Business Journal 20 315-336

Greene F J, Mole K F, Storey D J, 2004, "Does more mean worse? Three decades of enterprise policy in the Tees Valley" Urban Studies 41 1207-1228 
Greene F J, Mole K F, Storey D J, 2008, Three Decades of Enterprise Culture (Palgrave MacMillan, London)

Greene F J, Patel P, 2013, "Enterprise 2050: Getting UK enterprise policy right", https://www.gov.uk/government/uploads/system/uploads/attachment_data/file/225966 /19_ATTACHMENT_6.pdf

Grimshaw J M, Thomas R E, MacLennan G, Fraser C, Ramsay C R, 2003, "Effectiveness and Efficiency of Guideline Dissemination and Implementation Strategies", http://www.journalslibrary.nihr.ac.uk/_data/assets/pdf_file/0007/64852/FullReporthta8060.pdf

Guba E G, Lincoln Y S, 1994, "Competing paradigms in qualitative research" in Handbook of qualitative research Eds N K Denzin and Y S Lincoln (Sage, London) pp 105-117

HM Treasury, 2005, The Green Book - Appraisal and Evaluation in Central Government (TSO, London)

Hart D M, 2003, The emergence of entrepreneurship policy - governance, start-ups and growth in the US knowledge economy (Cambridge University Press, Cambridge)

Hill M, 2005, The Public Policy Process $4^{\text {th }}$ edition (Pearson Education Limited, Essex)

Hupe P L, Hill, M J, 2015, ““And the rest is implementation.' Comparing approaches to what happens in policy processes beyond Great Expectations" Public Policy and Administration DOI: 10.1177/0952076715598828

Huggins R, Williams N, 2009, "Enterprise and public policy: a review of Labour government intervention in the United Kingdom” Environment and Planning C: Government and Policy 27 19-41

Huggins R, Williams N, 2011, “Entrepreneurship and regional competitiveness: The role and progression of policy” Entrepreneurship \& Regional Development 23 907-932 
Huggins R, Morgan B, Williams N, 2014, "Regions as enterprising places: Governance, policy and development" Enterprising Places: Leadership and Governance Networks (Contemporary Issues in Entrepreneurship Research, Volume 3) Emerald Group Publishing Limited 3 1-28

Hülsbeck M, Lehmann E E, 2007, “Entrepreneurship Policy in Bavaria: Between Laptop and Lederhosen" in Handbook of Research on Entrepreneurship Policy Eds D B Audretsch, I Grilo, A R Thurik (Edward Elgar, Great Britain) pp 200-212

Jones P, Beynon M, Pickernell D, Packham G, 2013, "Evaluating the impact of different training methods on SME business performance" Environment and Planning C: Government and Policy 31 56-81

King N, 2012, "Using templates in the thematic analysis of text" in Essential Guide to Qualitative Methods in Organizational Research Eds C Cassell, G Symon (London, Sage) pp 256-271)

King N, Carroll C, Newton P, Dornan T, 2002, “'You can't cure it so you have to endure it': The experience of adaptation to diabetic renal disease" Qualitative Health Research $12329-346$

Kingdon J, 1984, Agendas, Alternatives and Public Policy (Little, Brown, Boston) Kvale S, 2007, Doing interviews (Sage, Thousand Oaks)

Lambrecht J, Pirnay F, 2005, “An evaluation of public support for private external consultancies to SMEs in the Walloon Region of Belgium" Entrepreneurship \& Regional Development 7 89-108

Lenihan H, 2011, “Enterprise policy evaluation: Is there a 'new' way of doing it?” Evaluation and Program Planning 34 323-332 
Lenihan H, Hart M, Roper S, 2005, “Developing an Evaluative Framework for Industrial Policy in Ireland: Fulfilling the Audit Trail or an Aid to Policy Development" Quarterly Economic Commentary, Summer 2005 16-85

Liddle J, 2010, “Twenty-first-century public leadership within complex governance systems: some reflections" Policy \& Politics 38 657-663

Lipsky M, 1980, Street-Level Bureaucracy (Sage Publications, New York)

Loader K, 2013, "Is public procurement a successful small business support policy? A review of the evidence" Environment and Planning C: Government and Policy 31 39-55

Lord Heseltine, 2013, "No Stone Unturned: In Pursuit of Growth" http://dera.ioe.ac.uk/16031/7/12-1213-no-stone-unturned-in-pursuit-ofgrowth_Redacted.pdf

Lord Young, 2015, The Report on Small Firms 2010-2015 (The Stationary Office, London)

Lundstrom A, Stevenson L, 2001, Entrepreneurship Policy for the Future: Best Practice Components paper presented at the Keynotes Presentation at the $46^{\text {th }}$ World Conference of the International Council for Small Business, Taiwan

Lundstrom A, Stevenson L, 2005, Entrepreneurship Policy - Theory and Practices (ISEN International Studies in Entrepreneurship) (Springer, Birkhäuser)

Macnee C L, McCabe S, 2008, Understanding nursing research: Using research in evidencebased practice (Williams \& Wilkins: Lippincott)

Marlow D, McCarthy A, O'Brien P, Pike A, Tomaney J, 2013, “The State of the LEPs: A National Survey" in Where Next for Local Enterprise Partnerships? Eds M Ward, S Hardy (The Smith Institute and Regional Studies Association, London) pp 66-47

Marshall C, Rossman G, 1995, Designing qualitative research (Sage Publications, Newbury Park) 
Maville A, 2012, “Enterprise Agencies: An English Model of Small Business Advice and Support" in Government, SMEs and Entrepreneurship Development Policy, Practice and Challenges Eds R A Blackburn, M T Schaper (Gower, Farnham) pp 211-225

May T, 2002, Qualitative research methods (Sage Publications, London)

McLaughlin M W, 1987, “Learning from Experience: Lessons from Policy Implementation” Education Evaluation and Policy Analysis 9 171-178

Miles M B, Huberman A M, 1994, Qualitative data analysis - an expanded sourcebook (Sage Publications, Newbury Park)

Mole K, 2002, "Street-level technocracy in UK small business support: Business Links, personal business advisers, and the Small Business Service" Environment and Planning C: Government and Policy 20 179-194

National Audit Office, 2006, "Supporting Small Business” https://www.nao.org.uk/wpcontent/uploads/2006/05/0506962.pdf National Audit Office, 2013, "Funding and Structures for Local Economic Growth”, https://www.nao.org.uk/wpcontent/uploads/2013/12/10285-001-Local-economic-growth.pdf

Neuwalaers C, Reid A, 2002, "Learning innovation policy in a market-based context: process, issues and challenges for EU candidate countries" Journal of International Relations and Development 5 357-379

Niska M, Vesala M, 2013, "SME policy implementation as a relational challenge" Entrepreneurship \& Regional Development 25 521-540

Nolan A, 2003, Entrepreneurship and local economic development: programme and policy recommendation (OECD, Paris)

North D, Smallbone D, 2006, "Developing entrepreneurship and enterprise in Europe's peripheral rural areas: Some issues facing policy-makers” European Planning Studies 14 41-60 
O’Connor A, 2015, “A conceptual framework for entrepreneurship education policy: Meeting government and economic purposes” Journal of Business Venturing 28 546-563

O'Toole L J, 2004, “The Theory-Practice Issue in Policy Implementation Research" Public Administration 82 309-329

Patton M Q, 2002, Qualitative Research and Evaluation Methods (Sage Publications, London)

Patton D, Marlow S, Ram M and Sanghera K, 2003, "Interpretive analysis as an evaluative tool: The case of Mustard.UK.Com, a high-growth small business programme" Environment and Planning C: Government and Policy 21 813-824

Peck F, Parry S, Mulvey G, Jackson K, Cabras I, Jackson J, 2014, “The role and significance of rates relief for supporting businesses in Wales" Environment and Planning C: Government and Policy 32 982-999

Pickernell, D, Atkinson C, Miller C, 2015, “Government SME intervention policy: perception is 9/10ths of the truth?" Environment and Planning C: Government and Policy 33 4-8

Pike A, Rodríguez Pose A, Tomaney J, 2006, Local and Regional Development (Routledge, Oxon)

Pressman J, Wildavsky A, 1973, Implementation: How Great Expectations in Washington Are Dashed in Oakland (University of California Press, Berkeley, CA)

Pugalis N, Shutt J, Bentley G, 2012, Critical Issues in Economic Development: Local Enterprise Partnerships: Living Up To The Hype? (Institute of Economic Development, London)

Pugalis L, Townsend, A R, 2015, Planning for Growth: The Role of Local Enterprise Partnerships in England: Final Report (Royal Town Planning Institute (RTPI), London) 
Richard D, 2008, Richard Review on Small Business \& Government http://www.conservatives.com/pdf/document-richardreport-2008.pdf.

Richards D, Smith M, 2006, "Central Control and Policy Implementation in the UK" Journal of Comparative Policy Analysis 8 325-45

Richards S, Barnes M, Sullivan H, Gaster L, Leach B, Coulson A, 1999, Cross-cutting issues in public policy and public service Department of Environment Transport and the Regions (University of Birmingham School Staff, Great Britain)

Rigby J, Ramlogan R, 2013, "The impact and effectiveness of entrepreneurship policy", http://www.nesta.org.uk/sites/default/files/the_impact_and_effectiveness_of_entrepre neurship.pdf

Robson P J A, Bennett R J, 2000, "The use of and impact of business advice in Britian: An empirical assessment using logit and ordered logit models" Applied Economics 32 $1675-1688$

Roper S, Hewitt D N, 2001, “Grant Assistance And Small Firm Development In Northern Ireland And The Republic Of Ireland” Scottish Journal of Political Economy 48 99117

Roper S, Hart M, 2013, "Supporting sustained growth among SMES - Policy models and guidelines”, http://www.enterpriseresearch.ac.uk/wp-content/uploads/2013/12/ERCWhite-Paper-No-7-Roper-Hart-Supporting-sustained-growth-2.pdf

Rush H, Bessant J, Lees S, 2004, “Assessing the effectiveness of technology policy - a longterm view" Technology Analysis \& Strategic Management 16 327-342

Shane S, 2009, "Why encouraging more people to become entrepreneurs is bad public policy” Small Business Economics 33 141-149 
Silversides G, 2001, "Networking and identity: The role of networking in the public image of professional service firms" Journal of Small Business and Enterprise Development $\mathbf{8}$ $174-184$

Smallbone D, Welter F, 2009, Entrepreneurship and Small Business Development in PostSocialist Economies (Routledge, Oxon)

Smallbone D, Welter F, 2010, "Entrepreneurship and government policy in former Soviet republics: Belarus and Estonia compared" Environment and Planning C: Government and Policy 28 195-210

Speziale H J S, Carpenter D R, 2003, "The conduct of qualitative research: Common essential elements" in Qualitative Research in Nursing: Advancing the Humanistic Imperative Eds H J S Speziale, D R Carpenter (Lippincott, Philadelphia) pp 15-26

Stevenson L, Lundström A, 2007, "Dressing the emperor: the fabric of entrepreneurship policy" in Handbook of research on entrepreneurship policy" Eds D B Audretsch, I Grilo, A R Thurik (Edward Elgar, Great Britain) pp 94-129

Storey D J, 2002, "Methods evaluating the impact of public policies to support small businesses: The six steps to heaven" International Journal of Entrepreneurship Education 1 181-202

Storey D J, Greene F, 2010, Small Business and Entrepreneurship (Pearson Education, Harlow)

Stoutenborough J W, Oxley D R, 2012, Improving the Likelihood of Effective Policy Outcomes: A Theory of Policy Diffusion Program Evaluation Institute for Science, Technology and Public Policy Bush School of Government and Public Service Texas A\&M University

Theodoulou S Z, Kofinis C, 2004, The Art of the Game: Understanding American Public Policy Making (Wadsworth, Belmont, CA) 
Thompson J, Scott J M, Downing R, 2012, “Enterprise policy, delivery, practice and research: Largely rhetoric or under-valued achievement" International Journal of Public Sector Management 25 332-345

Stevenson L, Lundström A, 2007 "Dressing the emperor: the fabric of entrepreneurship policy. Handbook of research on entrepreneurship policy" in Handbook of Research on Entrepreneurship Policy Eds D B Audretsch, I Grilo, A R Thurik (Edward Elgar, Great Britain) pp 94-129

Tummers, L G, Vermeeren B, Steijn B, Bekkers V, 2012, "Public Professionals and Policy Implementation: Conceptualizing and Measuring Three Types of Role Conflicts" Public Management Review 14 1041-1059

Tummers L G, Bekkers V, 2014, "Policy implementation, street-level bureaucracy, and the importance of discretion" Public Management Review 16 527-547

Urwin K, Jordan A, 2008, "Does public policy support or undermine climate change adaptation? Exploring policy interplay across different scales of governance" Global Environmental Change 18180-191

Van Cauwenberge P, Vander Bauwhede H, Schoonjans B, 2013,. "An evaluation of public spending: the effectiveness of a government-supported networking program in Flanders" Environment and Planning C: Government and Policy 31 24-38

Vega A, Chiasson M, Brown D, 2013, "Understanding the causes of informal and formal discretion in the delivery of enterprise policies: a multiple case study" Environment and Planning C: Government and Policy 31 102-118

Verheul I, Carree M, Santarelli E, 2009, "Regional opportunities and policy initiatives for new venture creation" International Small Business Journal 27 608-626

Ward 2015, "Local Enterprise Partnerships", http://researchbriefings.files.parliament.uk/documents/SN05651/SN05651.pdf 
Weatherley R, Lipsky M, 1977, "Street level bureaucrats and institutional information: Implementing special education reform” Harvard Educational Review 47 171-197

Weible C M, Heikkila T, Sabatie, P A, 2012, "Understanding and influencing the policy process" Policy Sciences 45 1-21

Williams N, Vorley T, 2014, "Economic resilience and entrepreneurship: Lessons from the Sheffield City Region” Entrepreneurship \& Regional Development 26 257-281

Woods M, Miles P, 2014, “Collaborative development of enterprise policy: a process model for developing evidence-based policy recommendation using community focused strategic conversations and SERVQUAL" International Journal of Public Sector Management 27 1-28

Wren C, Storey D J, 2002 "Evaluating the effect of soft business support upon small firm performance" Oxford Economics Papers 54 334-365

Wright M, Roper S, Hart M, Carter S, 2015, “Joining the dots: Building the evidence base for SME growth policy” International Small Business Journal 33 3-11

Xheneti M, Kitching J, 2011, "From discourse to implementation: enterprise policy development in postcommunist Albania" Environment and Planning C: Government and Policy 29 1018-1036 


\section{Figure 1: Organisational structure of responsibility}

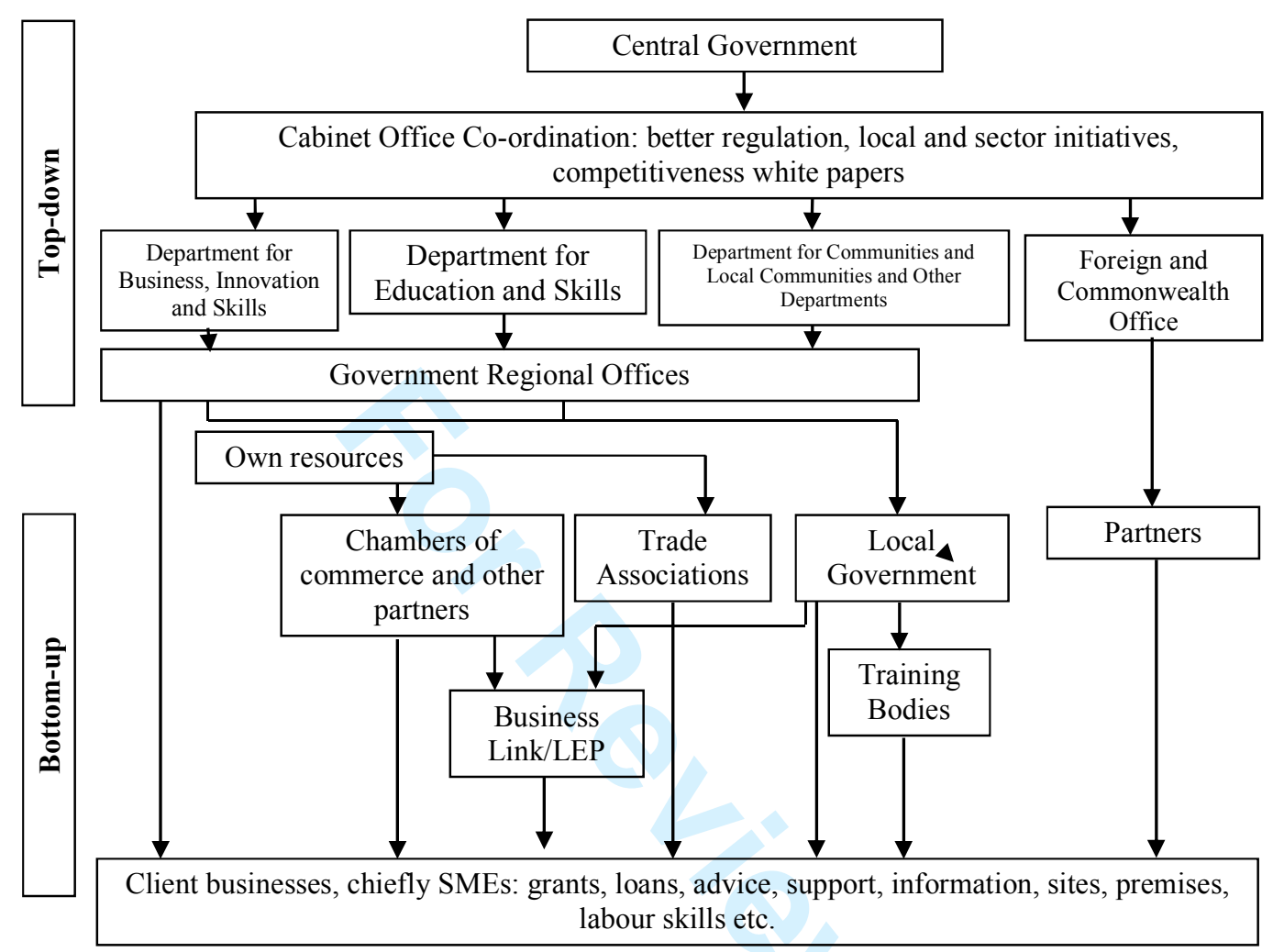

Source: Adapted from Bennett $(2012,71)$. 
Figure 2: Hierarchy of interviews

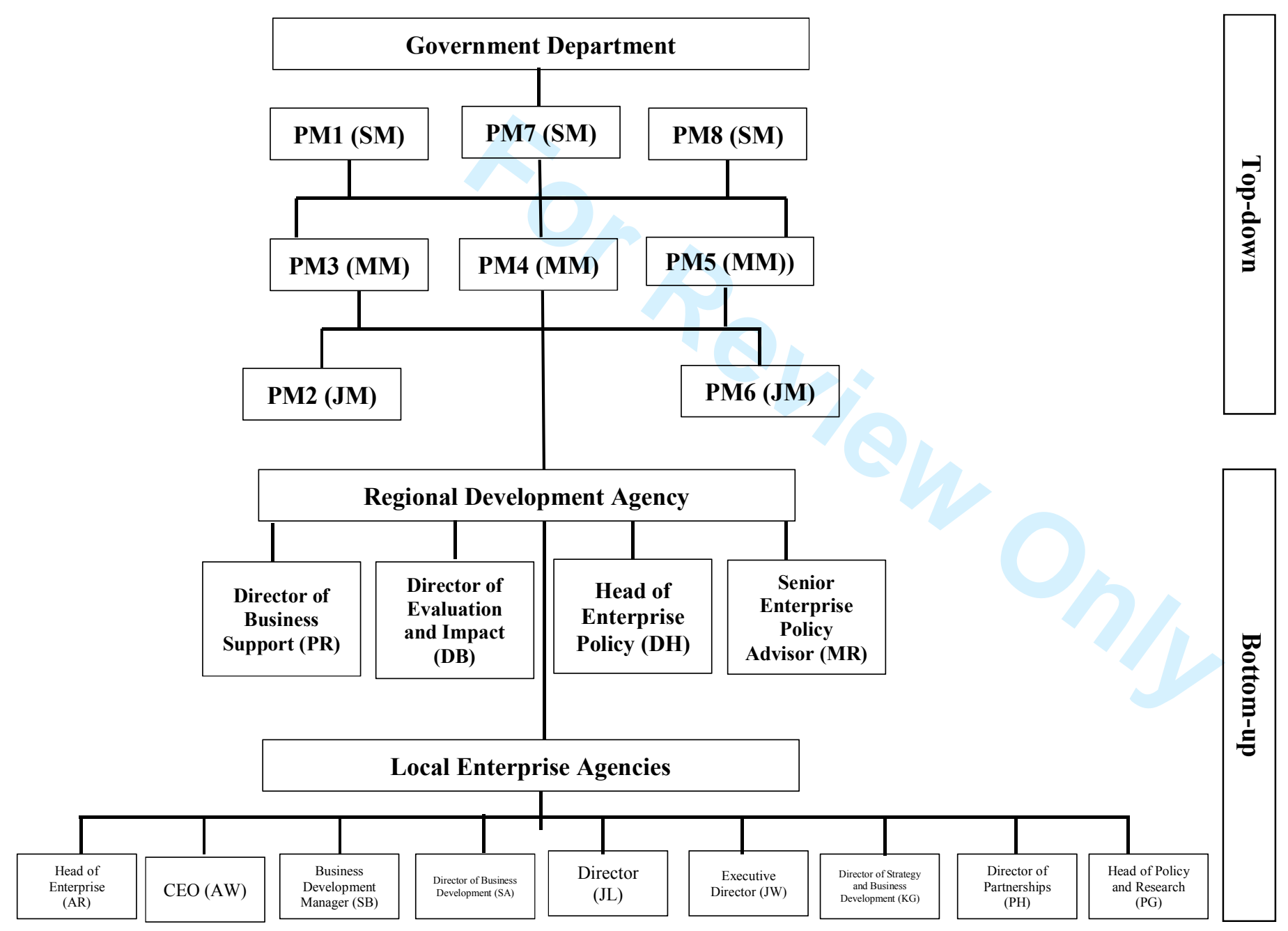


Figure 3: Summary of findings

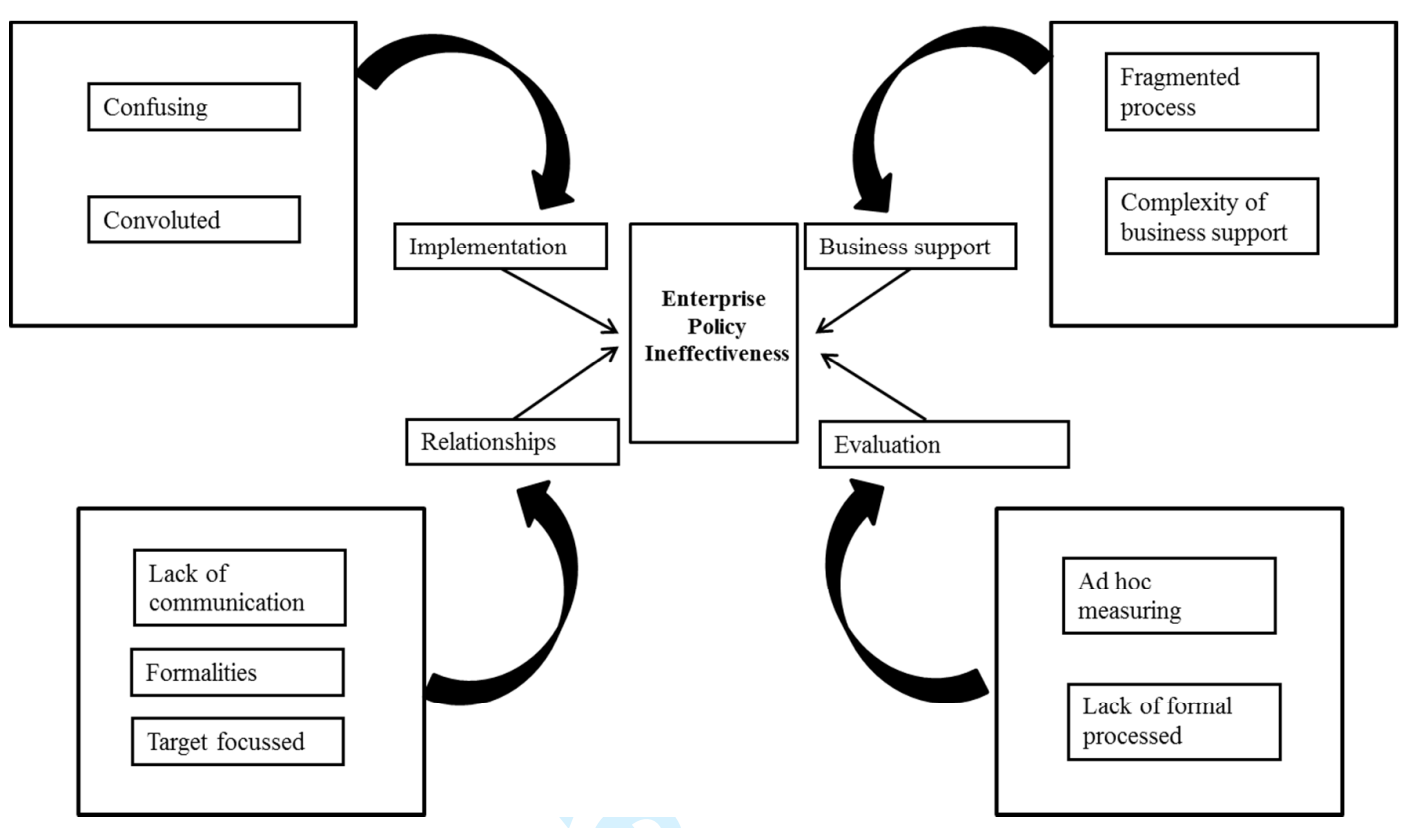


Table 1: Types of enterprise policy

\begin{tabular}{|l|l|l|}
\hline Policy type & Policy objectives & Example \\
\hline E-extension & $\begin{array}{l}\text { Start-up programmes 'added-on' to existing SME } \\
\text { initiatives where they tend to be somewhat } \\
\text { marginalised and weakly resourced. }\end{array}$ & $\begin{array}{l}\text { Taiwan, USA, } \\
\text { Australia, Canada } \\
\text { and Sweden }\end{array}$ \\
\hline 'Niche' & $\begin{array}{l}\text { The government formulates targeted } \\
\text { entrepreneurship around specified groups of the } \\
\text { population. }\end{array}$ & $\begin{array}{l}\text { US, Canada and } \\
\text { Sweden }\end{array}$ \\
\hline $\begin{array}{l}\text { New firm } \\
\text { creation }\end{array}$ & $\begin{array}{l}\text { The aim of this policy is to reduce time and costs } \\
\text { to a minimum so that more people will be able to } \\
\text { start their own businesses. }\end{array}$ & Italy \\
\hline Holistic & $\begin{array}{l}\text { National government policy objectives include } \\
\text { assisting start-ups and specific target groups as } \\
\text { well as supporting firm growth. }\end{array}$ & $\begin{array}{l}\text { UK, Sweden, } \\
\text { Canada }\end{array}$ \\
\hline
\end{tabular}

Source: Adapted from Stevenson and Lundstrom (2007), Verheul et al (2009) and Roper and Hart (2013).

Table 2: Interview guide themes

\begin{tabular}{|l|c|c|c|}
\hline \multirow{2}{*}{ Themes } & \multicolumn{3}{|l|}{ Interview groups } \\
\cline { 2 - 4 } & Policy-makers & RDA staff & Local Agencies \\
\hline $\begin{array}{l}\text { Objectives, policies, } \\
\text { programmes and structure }\end{array}$ & $\mathrm{x}$ & $\mathrm{x}$ & $\mathrm{x}$ \\
\hline SME/Entrepreneurship focus & $\mathrm{x}$ & $\mathrm{x}$ & $\mathrm{x}$ \\
\hline Implementation & $\mathrm{x}$ & $\mathrm{x}$ & $\mathrm{x}$ \\
\hline Relationships & $\mathrm{x}$ & $\mathrm{x}$ & $\mathrm{x}$ \\
\hline $\begin{array}{l}\text { Perceptions and experience of } \\
\text { enterprise policy and support }\end{array}$ & & $\mathrm{x}$ & $\mathrm{x}$ \\
\hline Evaluation & $\mathrm{x}$ & $\mathrm{x}$ & $\mathrm{x}$ \\
\hline
\end{tabular}


Table 3: Local agency relationships with RDAs and government

\begin{tabular}{|l|l|l|l|}
\hline $\begin{array}{l}\text { Initials of } \\
\text { names of } \\
\text { interviewees }\end{array}$ & Role & $\begin{array}{l}\text { Relationship with the government } \\
\text { department }\end{array}$ & Relationship with RDA \\
\hline JL & Local & $\begin{array}{l}\text { Only the fact that we are an approved } \\
\text { enterprise agency under the National } \\
\text { Federation of Enterprise Agencies } \\
\text { (NFEA) through [government } \\
\text { Aepartment] but no relationship exists. } \\
\text { But we would like to have a } \\
\text { relationship. }\end{array}$ & $\begin{array}{l}\text { They don't always listen but that's part of } \\
\text { their constraints they have from [RDA], but } \\
\text { very positive and no real problems. I value } \\
\text { what they try to do, it's just I think the way } \\
\text { the funding comes down is perhaps more } \\
\text { difficult than we envisage. }\end{array}$ \\
\hline JW & $\begin{array}{l}\text { We do talk to them but they normally } \\
\text { talk to us to ask our views, usually } \\
\text { what we think of XXX but we do try } \\
\text { to talk to them about policy. }\end{array}$ & $\begin{array}{l}\text { Ithink with [RDA] and with Business Link } \\
\text { it's a good business, a good professional } \\
\text { relationship, I don't think we're too cosy } \\
\text { with them but I don't think we're nasty to } \\
\text { them either. It's a professional relationship. }\end{array}$ \\
\hline SB & $\begin{array}{l}\text { Local } \\
\text { Agency }\end{array}$ & $\begin{array}{l}\text { No relationship with [government } \\
\text { department]. }\end{array}$ & $\begin{array}{l}\text { Our relationship with [RDA] is that we } \\
\text { haven't really got one because they are just } \\
\text { the people providing the money for the } \\
\text { contracts. Our relationship with Business } \\
\text { Link is quite a close one, its constant contact. }\end{array}$ \\
\hline
\end{tabular}

